\title{
Variable Induction of Pro-inflammatory Cytokines by Commercial SARS CoV-2 Spike Protein Reagents: Potential Impacts of LPS on In Vitro Modeling and Pathogenic Mechanisms In Vivo
}

Weiming Ouyang ${ }^{\mathrm{a}}$, Tao Xie ${ }^{\mathrm{a}}$, Hui Fang ${ }^{\mathrm{a}}$, Chunling Gao ${ }^{\mathrm{b}}$, Tzanko Stantchev ${ }^{\mathrm{b}}$, Kathleen A. Clouse ${ }^{\mathrm{b}}$, Kun Yuan $^{\mathrm{c}}$, Tongzhong Juc ${ }^{\mathrm{c}}$, David M. Frucht ${ }^{\mathrm{a}, 1}$

${ }^{a}$ Division of Biotechnology Review and Research II, ${ }^{b}$ Division of Biotechnology Review and Research I, and ${ }^{c}$ Division of Biotechnology Review and Research III, Office of Biotechnology Products, Office of Pharmaceutical Quality, Center for Drug Evaluation and Research, U.S. Food and Drug Administration

${ }^{1}$ To whom correspondence should be addressed.

David M. Frucht, M.D.

Division of Biotechnology Review and Research II

Office of Biotechnology Products, Office of Pharmaceutical Quality

Center for Drug Evaluation and Research, U.S. Food and Drug Administration

10903 New Hampshire Ave, Silver Spring, MD 20993

Phone: 240-402-9533

E-mail: david.frucht@fda.hhs.gov 


\begin{abstract}
Proinflammatory cytokine production following infection with severe acute respiratory syndrome coronavirus 2 (SARS CoV-2) is associated with poor clinical outcomes. Like SARS CoV-1, SARS CoV-2 enters host cells via its spike protein, which attaches to angiotensin-converting enzyme 2 (ACE2). As SARS $\mathrm{CoV}-1$ spike protein is reported to induce cytokine production, we hypothesized that this pathway could be a shared mechanism underlying pathogenic immune responses. We herein compared the capabilities of Middle East Respiratory Syndrome (MERS), SARS CoV-1 and SARS CoV-2 spike proteins to induce cytokine expression in human peripheral blood mononuclear cells (PBMC). We observed that only specific commercial lots of SARS CoV-2 induce cytokine production. Surprisingly, recombinant SARS CoV-2 spike proteins from different vendors and batches exhibited different patterns of cytokine induction, and these activities were not inhibited by blockade of spike protein-ACE2 binding using either soluble ACE2 or neutralizing anti-S1 antibody. Moreover, commercial spike protein reagents contained varying levels of endotoxin, which correlated directly with their abilities to induce cytokine production. The lipopolysaccharide (LPS) inhibitor, polymyxin B, blocked this cytokine induction activity. In addition, SARS CoV-2 spike protein avidly bound soluble LPS in vitro, rendering it a cytokine inducer. These results not only suggest caution in monitoring the purity of SARS CoV-2 spike protein reagents, but they indicate the possibility that interactions of SARS CoV-2 spike protein with LPS from commensal bacteria in virally infected mucosal tissues could promote pathogenic inflammatory cytokine production.
\end{abstract}

Keywords: SARS CoV-2, COVID-19, spike protein, ACE2, proinflammatory cytokine, endotoxin

\title{
Introduction
}

SARS CoV-2 is the etiological agent responsible for a global pandemic that, as of May $26^{\text {th }}, 2021$, has led to 168.8 hundred million cases and over 3.5 million deaths (1). This virus is a member of the beta-coronavirus family and shares 79.5\% sequence homology with SARS CoV-1 (2), which emerged in Southeast Asia in 2003, causing a limited epidemic (3-5). Similar to SARS CoV-1 (6), SARS CoV-2 enters host cells via its surface spike protein, which binds ACE2 on host cells (7-9). SARS CoV-2 spike protein exists as a trimer, with three receptor-binding S1 heads located on top of a trimeric membrane fusion S2 stalk. The receptorbinding domain (RBD) of the S1 subunit specifically recognizes ACE2. Protease-mediated cleavage of the spike protein at the S1/S2 boundary leads to S1 dissociation and S2-mediated membrane fusion $(10,11)$.

During viral infection, host cells recognize the pathogen-associated molecular patterns (PAMPs) of the virus. For example, viral double-stranded RNA (dsRNA) is sensed by the pathogen recognition receptors (PRRs), which include the retinoic acid-inducible gene I (RIG-I)-like receptors (RLRs; RIG-I and melanoma differentiation associated protein 5 [MDA-5]) $(12,13)$ and the toll-like receptors (TLRs) (14-16). Recognition of SARS CoV-2 viral RNAs by these PRRs triggers the expression of type I IFN and other proinflammatory cytokines $(17,18)$. IFN production during the early phase of viral infection is critical for the host to restrain replication of the virus. During evolution in their natural hosts (bats), coronaviruses have acquired the ability to suppress the early phase IFN response by multiple mechanisms, including shielding of the dsRNA in double-membrane vesicles, which prevent the sensing by PRRs, inhibiting host protein synthesis, and disrupting essential signal transduction (17,19-23). While IFN production is blocked in most cell types following coronavirus infection, notable exceptions are plasmacytoid dendritic cells (pDCs), which sense single strand RNA via toll-like receptor 7 (TLR-7) and express high levels of type I IFN in response to coronavirus infection (19). A delayed IFN response, together with high load of virus and proinflammatory cytokines causes an unbalanced immune state, promoting the progression of COVID-19 disease (24-32). Severe COVID-19 patients exhibit high levels of pro-inflammatory cytokines, lymphopenia, $\mathrm{T}$ cell 
exhaustion and increased neutrophil-to-lymphocyte ratios, which correlate with poor clinical outcomes.

SARS CoV-1 and SARS CoV-2 infect host cells by a similar mechanism $(7,8)$. However, the viral shedding pattern and disease progression following infection differ between these two viruses (33). Also, SARS CoV2 causes a higher viral load than SARS CoV-1 during the early phase of infection (33), but the reason for this difference is not clear. Interestingly, SARS CoV-1 spike protein has been reported to induce cytokine responses following its direct binding to ACE2 (34). Given that SARS CoV-2 spike protein has a higher binding affinity to ACE2 than SARS CoV-1 spike protein $(9,10)$, we reasoned that SARS CoV-2 spike protein might induce a more robust cytokine response than SARS CoV-1 in human PBMC. In this study, we report that some commercial lots of SARS CoV-2 spike protein-containing fusion proteins, but not lots of SARS CoV-1 or MERS spike protein-containing fusion proteins, stimulate human PBMC to produce proinflammatory cytokines. Unexpectedly, induction of cytokine production by SARS CoV-2 spike fusion proteins consistently exhibits vendor and batch variability, and cytokine inductions are not blocked by soluble ACE2 or neutralizing anti-spike protein antibody. Instead, we find that commercial spike fusion protein-containing reagents contain variable levels of endotoxin, which, in turn, correlate with their activities to induce cytokine production. The cytokine-inducing activities of spike fusion protein reagents are blocked by polymyxin B, a lipopolysaccharide (LPS) inhibitor. SARS CoV-2 spike protein efficiently captures soluble LPS, rendering it capable of potent pro-inflammatory cytokine induction. Collectively, these findings indicate that co-purifying LPS, but not spike protein itself, induces proinflammatory cytokine responses in human PBMC. These findings not only highlight the need to monitor LPS levels during in vitro and in vivo studies involving recombinant SARS CoV-2 spike protein, but they suggest a potential role for this interaction in virally infected tissues that harbor commensal bacteria.

\section{Results}

SARS CoV-2 spike protein-containing fusion proteins induce cytokine production in human PBMC. To investigate the capability of SARS CoV-2 spike protein to directly induce a cytokine response, we cultured human PBMC from two healthy donors with a commercial SARS CoV-2 S1-Fc fusion protein (Vendor \#1, lot 24056-2002-2). Following a 48-hour stimulation, levels of IL-1ß, IL-6, IL-8, IL-10, IL-12 and TNF $\alpha$ were assessed by flow cytometry using a human inflammatory cytometric bead array (CBA) kit. Because IL-8 levels in some samples were too high to be accurately measured by the CBA assay, they were determined by ELISA. IL-6, IL-8, IL-10 and TNF $\alpha$ were detected in the supernatants of SARS CoV-2 S1Fc-treated PBMC from both donors in a dose-dependent manner (Fig. 1). We next directly compared the cytokine-inducing capabilities of MERS S1-Fc and SARS CoV-1 S1-Fc (Vendor \#2), as well as SARS CoV2 S1-Fc and RBD-Fc proteins from two commercial sources (Vendor \#1 and Vendor \#2). SARS CoV-2 S1Fc from Vendor\#2 and SARS CoV-2 RBD-Fc from Vendor\#1 induced robust cytokine responses following 24-hour culture, whereas the other fusion protein reagents or an IgG1 monoclonal antibody control (raxibacumab) did not (Fig. 2A). Although cytokines were induced by two of the SARS CoV-2 reagents, there was no clear pattern between the manufacturer and/or fusion construct with respect to cytokine induction activity. It was also surprising that SARS CoV-1 S1-Fc fusion protein did not induce the expression of IL-6, IL-8 and TNF $\alpha$, which is contradictory to the previous report (34). In addition, to exclude a potential impact of FcR crosslinking by the Fc fusion proteins on the cytokine response, we performed experiments using biotinylated S1 and RBD proteins together with plate-bound streptavidin to stimulate human PBMC. As observed with $\mathrm{S} 1$ and RBD fusion protein reagents without biotin (Vendor \#2), crosslinked S1-biotin but not RBD-biotin induced a robust cytokine response in human PBMC, suggesting that FcR crosslinking did not play a role (Fig. 2B). 
Inhibition of SARS CoV-2 spike fusion protein-induced cytokine response by budesonide and MAPK inhibitors. Early treatment with inhaled budesonide has been reported to dampen inflammation in COVID19 patients (35). Consistent with these findings, co-culture of PBMC with budesonide inhibited S1-Fcinduced production of IL-6, IL-8 and TNFa (Fig. 3). As SARS CoV-2 spike protein has been reported to activate the MAPK and NF- $\mathrm{BB}$ signaling pathways (36), and the NFAT signaling pathway is involved in cytokine induction in many cells $(37,38)$, we next investigated whether S1-Fc-induced cytokine responses are blocked by inhibitors targeting these signaling pathways. Treatment with NFAT and NF- $\mathrm{B}$ inhibitors did not decrease S1-Fc-induced expression of proinflammatory cytokines (Fig. S1). In contrast, JNK1/2 inhibition reduced the induction of IL-6, IL-8 and TNF $\alpha$; p38 inhibition reduced the induction of IL-6 and TNF $\alpha$; and Erk1/2 inhibition reduced TNF $\alpha$ induction (Fig. 3).

SARS CoV-2 spike fusion protein-induced cytokine response is independent of its binding to ACE2. During the investigation of the capability of SARS CoV-2 spike protein to induce a cytokine response, we noticed that SARS CoV-2 S1-Fc protein reagent from Vendor \#2, but not Vendor \#1 (lot 24529-2003), and RBD-Fc from Vendor \#1, but not Vendor \#2, induced cytokine responses. In addition, batch variability in PBMC cytokine induction capacity was observed between S1-Fc and RBD-Fc protein lots purchased from Vendor \#1 (Fig. S2). We reasoned that these inconsistencies could be due to product quality differences affecting spike protein binding to ACE2. To test this hypothesis, we developed an ELISA to measure the binding affinities of spike fusion protein constructs with ACE2. In this assay, ACE2 was coated on a plate, exposed to spike protein-containing test reagents, followed by incubation with HRP-labelled anti-human IgG Fc antibody and substrate development (Fig. S3). Absorbance values at 450nm correlated linearly with the concentrations of S1-Fc protein (Fig. S3). Using this ELISA, we observed that SARS CoV-2 S1-Fc and RBD-Fc from both Vendor \#1 and Vendor \#2, as well as SARS CoV-1 S1-Fc, showed dose-dependent binding to ACE2, which did not correlate with their abilities to induce cytokine production (Fig. 4A). Moreover, blockade of S1-Fc binding to ACE2 by soluble ACE2 and an anti-S1 neutralizing antibody did not block S1-induced production of IL-6, IL-8 or TNF $\alpha$, despite blocking binding of the fusion proteins to ACE2 (Fig. 4B, 4C and Fig. S4). Of note, low levels of IL-8 production were observed in PBMC cultured with soluble ACE2 (Fig. 4C) or anti-S1 antibody alone (Fig. S4). Taken together, our results suggest that the induction of key pro-inflammatory cytokines in human PBMC by certain commercial S1-Fc-fusion proteins occurs independent of ACE2 binding.

LPS present in commercial SARS CoV-2 spike fusion preparations induces cytokine production. Spike fusion proteins purchased for our study from commercial vendors were expressed in mammalian cells and purified by a standard protein purification process. Both Vendor \#1 and Vendor \#2 report a control limit of < $1 \mathrm{EU} / \mu \mathrm{g}$ protein for the levels of endotoxin in their protein reagents. One possible explanation for the variation of S1-Fc and RBD-Fc abilities to induce cytokine response was due to variable levels of endotoxin present in these protein preparations. To test this hypothesis, we measured the levels of LPS in the fusion proteins used in our study using a limulus amebocyte lysate (LAL) chromogenic endotoxin quantitation assay. High levels of endotoxin were observed in SARS CoV-2 S1-Fc (lot 24056-2002-2) from Vendor\#1 and SARS CoV-2 S1-Fc from Vendor \#2 (Fig. 5A), correlating directly with their strong activities to induce cytokine production (Fig. 2). In contrast, the commercial SARS CoV-1 S1-Fc fusion protein had a low level of LPS, in line with its inability to induce a cytokine response (Fig. 2). Interestingly, LPS in these SARS CoV-2 S1-Fc protein preparations was not efficiently reduced following treatment of endotoxin removal using Pierce ${ }^{\mathrm{TM}}$ high capacity endotoxin removal spin columns (Fig. 5B). The S1-Fc fusion protein still induced a robust cytokine response following two rounds of endotoxin removal treatment (Fig. S5). This is consistent with a previous report that LPS binds SARS CoV-2 spike protein with a high affinity (39). 
LPS is known to induce a robust cytokine response following a short time period of stimulation (40). A timecourse study showed that a strong cytokine response was induced as early as 3 hours following S1-Fc protein stimulation, consistent with the hypothesis that the induced cytokine responses were due to the presence of LPS. We next obtained additional spike proteins from Vendor \#3, which has a 10-fold tighter control for the levels of endotoxin ( $<0.1 \mathrm{EU} / \mu \mathrm{g}$ protein). The low endotoxin levels in these proteins were confirmed using the LAL chromogenic endotoxin quantitation kit (Fig. S6A). Consistent with a role for LPS, these protein preparations did not induce a robust cytokine response in human PBMC following 3- and 24-hour stimulations (Fig. S6B). To further confirm that co-purifying LPS allows spike proteins to induce cytokine production, we cultured human PBMC with Vendor \#2 S1-Fc for 3 hours together with or without polymyxin B, an LPS inhibitor. S1-Fc-induced production of IL-6, IL-8 and TNF $\alpha$ was inhibited in the presence of polymyxin B (Fig. 5D, 5E). Taken together, these results indicate that co-purifying LPS, but not the spike protein itself, is responsible for the proinflammatory cytokine production in human PBMC.

SARS CoV-2 spike protein efficiently captures LPS, enabling cytokine induction activity. We next investigated in our study whether SARS CoV-2 S1-Fc and LPS synergistically induce cytokine responses. SARS CoV-2 S1-Fc lot 24529-2003 with a low level of co-purifying endotoxin (Fig. 5A) from Vendor \#1 was used to stimulate human PBMC together with five serially diluted concentrations of LPS (from 100 $\mathrm{mEU} / \mathrm{mL}-6.25 \mathrm{mEU} / \mathrm{mL}$ ). The presence of S1-Fc did not change the cytokine expression in human PBMC co-cultured with LPS (Fig. S7), suggesting that SARS CoV-2 S1-Fc does not have a synergistic effect on LPS-induced cytokine production in our experimental system. These results differ from the original report describing the LPS/SARS CoV-2 spike protein interaction (37).

Given that LPS is potentially present at sites of SARS CoV-2 infection, and that LPS binds the viral spike protein with a high affinity (39), we reasoned that SARS CoV-2 spike protein may serve as a scaffold to capture soluble environmental LPS, thereby facilitating the access of LPS to innate immune cells in infected tissues. We tested this hypothesis using plate-bound streptavidin, following by incubation with S1-biotin together with serially diluted LPS. Following thorough washing to remove unbound LPS, human PBMC were added to the wells and cultured for 3 hours. As shown in Fig. 6, PBMC cultured in the wells with S1biotin and LPS produced significantly higher levels of IL-6, IL-8 and TNF $\alpha$ than those cultured in wells with LPS alone, supporting our hypothesis that SARS CoV-2 spike protein efficiently captures LPS, forming complexes that activate immune cells to produce proinflammatory cytokines.

\section{Discussion}

Infection with SARS CoV-2 causes no symptoms or mild illness (COVID-19) that resolves spontaneously in most individuals $(41,42)$. However, a small proportion of patients with COVID-19 progress to a severe disease $(41,42)$. Severe disease is associated with an imbalanced immune response marked by delayed type I interferon responses to SARS CoV-2 and late-stage overproduction of proinflammatory cytokines (24-32). SARS CoV-1 spike protein is reported to activate immune cells by direct binding to ACE to produce proinflammatory cytokines (34). As SARS CoV-2 spike protein has a higher binding affinity to ACE2 than SARS CoV-1 spike protein (9), this led to our original hypothesis that SARS CoV-2 spike protein might directly induce a robust cytokine response via its interaction with ACE2. Investigation of this potential mechanism was warranted, because SARS CoV-2 spike protein is the target antigen for SARS CoV-2 vaccines and for neutralizing antibody therapies $(7,8)$. Moreover, investigation of cytokine induction by engagement of SARS CoV-2 spike protein with ACE2 had the potential to be the basis for a cell-based assay to evaluate the potency of FDA-regulated antibodies targeting SARS CoV-2 spike protein for COVID-19 therapies. 
Initial experiments using S1-Fc fusion protein manufactured by a commercial vendor using transient transfection of Expi293F cells demonstrated that this fusion protein exhibited a dose-dependent induction of cytokine expression in human PBMC, in line with our hypothesis. However, subsequent experiments involving a variety of commercial S1 protein constructs demonstrated inconsistencies between commercial vendors, as well as lot-to-lot variability in cytokine induction activity. Moreover, several orthogonal methods showed that cytokine induction was independent of ACE2 binding. These contradictory findings called into question our original hypothesis.

As the commercial spike fusion proteins used in this study were generated in mammalian cell culture systems, we did not expect significant levels of LPS to be present in these preparations. We nevertheless explored the possibility that variable levels of LPS underlay the inconsistency of these protein preparations to induce cytokine production. Surprisingly, results from LAL assays revealed that the capability of the commercial S1 fusion proteins to induced cytokines directly correlated with their levels of LPS, and the pattern and time course of cytokine induction by these reagents closely matched that of LPS (40). More convincing evidence supporting the role of the LPS pathway was the observation that S1-Fc-induced cytokine production was blocked by the LPS inhibitor, polymyxin B. In addition, blockade of MAPK signaling pathways but not the NF- $\mathrm{B}$ pathway, inhibited cytokine induction by S1-Fc. These findings are consistent with a previous report that p38 and JNK1/2 pathways are central to LPS-induced cytokine responses (43). Interestingly, SARS CoV-1 spike protein-induced IL-6 and TNF $\alpha$ in murine RAW264.7 cells was reported to be mediated by the NF- $\mathrm{B}$ pathway by the She group (34), suggesting a different mechanism might be involved.

The topic of SARS CoV-2 spike protein-induced cytokine production has been an area of active research, leading to somewhat contradictory conclusions. For example, Hsu et al. report that SARS CoV-2 spike protein promotes hyper-inflammatory response in human bronchial epithelial cells via ACE2-triggered MAP kinases - NF- $\mathrm{B}$ signaling pathways (36), a result that contrasts with our findings. Although we cannot exclude a role for cell-specific effects, their source for S1-His and RBD-His was Vendor \#2, whose controls on endotoxin levels (1 EU/ $\mu$ g protein) allow cytokine-inducing levels of LPS to be present in experimental conditions. Instead, our conclusions regarding a pro-inflammatory role for co-purifying LPS in commercial SARS CoV-2 spike protein preparations are consistent with Petruk et al, who report that LPS binds to both SARS CoV-1 and SARS CoV-2 spike proteins with high affinity, rendering complexes capable of inducing cytokines, independent of the NF- $\mathrm{B}$ pathway (36). However, we did not observe the synergistic effect between S1-Fc and LPS reported by Petruk et al, perhaps due to the different spike protein preparations and spike protein:LPS ratios employed in our experiments. Our results also are consistent with the report from the Shirato group, who reported that the SARS CoV-2 spike protein S1 subunit induces pro-inflammatory responses via toll-like receptor 4 signaling in murine and human macrophages, the signaling pathway downstream of LPS recognition (44). We note that the SARS CoV-1 and SARS CoV-2 spike proteins used in the studies of the She group and the Shirato group, respectively, were prepared using E. coli expression systems, where high-affinity binding to LPS would be very likely $(34,44)$.

IL-8 is a neutrophil chemotactic factor. High levels of serum IL-8 and an increased neutrophil-to-lymphocyte ratio are associated with the illness severity of COVID-19 (45). In this study, we observed that low levels of IL-8 are induced by MERS S1-Fc, SARS CoV-1 S1-Fc, SARS CoV-2 S1-Fc (Vendor\#1, lot 24529-2003) and SARS CoV-2 RBD-Fc (Vendor\#2 and Vendor\#1, lot 25130-2004 ) (Fig. 2 and Fig. S2), which do not induce expression of other inflammatory cytokines. In addition, polymyxin B completely blocks S1-Fcinduced IL-6 and TNF $\alpha$, but not IL-8. These observations may suggest a potential role for S protein-ACE2 interactions in driving IL-8 induction. However, PBMC cultured with soluble ACE2 (Fig. 4C) or anti-S1 antibodies alone (Fig. S4) also produce low levels of IL-8. Moreover, PBMC cultured with $0.35 \mathrm{mEU} / \mathrm{mL}$ of 
LPS for $24 \mathrm{~h}$ or $1.76 \mathrm{mEU} / \mathrm{mL}$ of LPS for $3 \mathrm{~h}$ results in low level production of IL-8 (Fig. S8). The existence of low levels of LPS in the reagents used to stimulated PBMC in this study is very likely. Taken together, the contribution of the interaction between SARS CoV-2 spike protein and ACE2 to IL-8 induction is likely negligible, although it cannot be fully excluded.

SARS CoV-2 spike protein is highly glycosylated (46). Glycans of the spike protein can bind C-type lectin receptors (CLRs) on immune cells (47), thereby promoting expression of proinflammatory cytokines. In future studies, we plan to investigate whether glycan profiles differ between various commercial SARS CoV2 spike protein-containing fusion proteins and the extent to which glycans contribute to cytokine responses induced by these proteins. Our finding that polymyxin B blocks cytokine induction suggests that a direct effect mediated through lectin receptors is unlikely, but the possibility exists that glycosylation of spike protein modulates its binding to LPS.

In summary, our findings confirm that SARS CoV-2 spike protein avidly binds LPS (39), introducing a potentially confounding factor in experimental studies. Careful monitoring of SARS CoV-2 spike protein reagents for LPS contamination is needed when these reagents are used for in vitro and in vivo studies. The strong binding activity of the spike protein with LPS enables the spike protein to function as a scaffold to capture LPS in vitro and, presumably, in vivo in virally infected mucosal tissues with abundant commensal bacteria. Moreover, as patients with certain COVID-19 risk factors such as diabetes and obesity are characterized by increased levels of Gram negative commensal bacteria in potential sites of infection such as the lung (48), this interaction could underlie a potential pathogenic mechanism intensifying damaging inflammation in susceptible patient groups.

\section{Materials and Methods}

\section{Human peripheral blood mononuclear cells}

Leukapheresis blood packs from healthy donors were obtained under an institutional review board-approved protocol at the National Institutes of Health. All donors provided written informed consent, and anonymized samples were provided to our laboratory. Cell preparations were performed following the approved laboratory guidelines. Peripheral blood mononuclear cells (PBMC) were prepared by Ficoll density gradient centrifugation. Cells were rested in RPMI 1640 medium supplemented with 10\% fetal-bovine serum, 2 mM L-glutamine, $100 \mathrm{IU} / \mathrm{mL}$ penicillin, $100 \mu \mathrm{g} / \mathrm{mL}$ streptomycin, $1 \mathrm{mM}$ sodium pyruvate, non-essential amino acids, $10 \mathrm{mM}$ HEPES and $55 \mu \mathrm{M}$ 2-mercaptoethanol overnight before stimulation. Rested PBMC were stimulated with spike Fc fusion protein preparations, with or without plate-bound streptavidin together with biotinylated spike proteins, or LPS captured by plate-bound streptavidin together with biotinylated SARS CoV-2 spike protein S1 subunit.

\section{Reagents}

S1-Fc (Catalog \# 97-086, lots 24056-2002-2 and 24529-2003), RBD-Fc (Catalog \# 10-206, lots 24530-2003 and 25130-2004), S1-biotin (Catalog \# 10-208 lot 24598-2003) were obtained from ProSci Inc (Vendor \#1; Poway, CA). MERS and SARS CoV-1 S1-Fc fusion proteins were prepared by Sino Biological (Vendor \#2; Beijing, China) under request. S1-Fc (Catalog\# 40591-V02H, lot LC14AP1605), RBD-Fc (Catalog\# 40592V02H, lot LC14MC2602), S1-biotin (Catalog\# 40591-V27HB, lot LC14AU101), RBD-biotin (Catalog\# 40592-V27B-B, lot MF14AP2302), ACE2 (Catalog\# 10108-H08H, lot MB14JN0906), anti-S1 neutralizing antibody (Catalog\# 40591-MM43, lot HB14AP2001) and anti-S1 non-neutralizing antibody (Catalog \# 40591-MM42, lot HB14AP0701) were also purchased from Sino Biological (Vendor \#2). S1-Fc (Catalog \# 10623-CV, lot DONK0120091) and S1-biotin (Catalog \# BT10569, lot DOJW120092) were purchased from R\&D Systems (Vendor \#3; Minneapolis, MN). Streptavidin (Catalog\# 85878-10MG, lot 049K8616V) and 
LPS from E. coli O111:B4 (Catalog\# L2630-10MG, lot 114M4009V) were purchased from Sigma (St. Louis, MO). Budesonide (Catalog\# S1286), MEK1/2 inhibitor U0126 (Catalog\# S1102), JNK1/2 inhibitor SP600125 (Catalog\# 1460), p38 inhibitor SB203580 (Catalog\# S1076), NFAT inhibitor Cyclosporin A (Catalog\# S2286) and NF-kB inhibitor JSH-23 (Catalog\# S7351) were purchased from Selleckchem (Houston, TX). NF-кB SN50 cell permeable inhibitory peptide (Catalog\# sc-3060) was obtained from Santa Cruz (Dallas, TX). Polymyxin B (Catalog\# ICN10056505) was obtained from Fisher Scientific (Waltham, MA). Budesonide was used at concentration of $50 \mathrm{nM}$. U0126, SP600125, SB203580 and NF- $\mathrm{B}$ SN50 cell permeable inhibitory peptide were used at final concentrations of $10 \mu \mathrm{M}$. Cyclosporin A, JSH-23 and polymyxin B were used at concentrations of $100 \mathrm{nM}, 50 \mu \mathrm{M}$ and $25 \mu \mathrm{g} / \mathrm{mL}$, respectively.

\section{Cytometric bead array of inflammatory cytokines}

The human inflammatory cytometric bead array (CBA) kit was purchased from BD Biosciences (San Jose, CA). This kit was used to measure the levels of IL-1 $\beta$, IL-6, IL-8, IL-10, IL-12p70 and TNF $\alpha$ following the manufacturer's instructions in supernatants collected from stimulated PBMC. Briefly, $50 \mu \mathrm{L}$ of mixed beads were incubated with $50 \mu \mathrm{L}$ of samples or standards and PE-labeled detecting antibodies at room temperature for 3 hours. Following one wash of the beads with wash buffer, the beads were resuspended in $100 \mu \mathrm{L}$ of buffer and analyzed by flow cytometry. Flow cytometry data were analyzed using FlowJo (Tree Star). The concentrations of cytokines were calculated based on interpolation from a curve generated using the data from the kit's standards. A stimulation index was calculated using the following formula: cytokine level of stimulated PBMC/cytokine level of untreated PBMC, or cytokine mean fluorescence intensity (MFI) of stimulated PBMC/cytokine MFI of untreated PBMC.

\section{IL-8 ELISA}

The levels of IL-8 in the supernatants were measured using the IL-8 ELISA kit (Catalog\# S8000C) purchased from R\&D Systems following the manufacturer's instructions. Supernatants were diluted based on the fluorescence intensities of IL-8 determined by the CBA assay. $50 \mu \mathrm{L}$ of diluted samples and standards were added to each well of the precoated ELISA plate and incubated for 2 hours at room temperature. Following 4 washes with wash buffer, $100 \mu \mathrm{L}$ of human IL-8 conjugate was added to each well and incubated for 1 hour at room temperature. Following 4 washes with wash buffer, $200 \mu \mathrm{L}$ of substrate solution was then added to each well and incubated for 30 minutes at room temperature. Substrate development was stopped by adding $50 \mu \mathrm{L}$ of stop solution to each well. Absorbance at $450 \mathrm{~nm}$ was measured using an ELISA plate reader. The concentrations of IL-8 in supernatants were calculated based on the standard curve and multiplied the dilution factors. A stimulation index was calculated using the following formula: IL-8 concentration of stimulated PBMC/IL-8 concentration of untreated PBMC.

\section{Spike protein binding assay}

An ELISA was developed to measure the binding activities of spike proteins with ACE2. $100 \mu \mathrm{L}$ of $2 \mu \mathrm{g} / \mathrm{mL}$ ACE2 in PBS was added to each well of a 96-well ELISA plate and incubated at $4{ }^{\circ} \mathrm{C}$ overnight. Following 3 washes with PBS, the wells were blocked with 2\% BSA in PBS containing 0.5\% tween-20 (PBST) at room temperature for 1 hour. The wells were then incubated with $100 \mu \mathrm{L}$ of serially diluted spike protein samples in PBST containing 0.1\% BSA at room temperature for 1 hour. Following 3 washes with PBST, $100 \mu \mathrm{L}$ of HRP-labelled anti-human IgG Fc antibody (Catalog\# 31413, Thermo Fisher) was added to each well and incubated for 1 hour. $100 \mu \mathrm{L}$ of substrate (Catalog\# 34028, Thermo Fisher) was added to each well following 4 washes with PBST and incubated at $37^{\circ} \mathrm{C}$ for 20 minutes. The development was stopped by adding $50 \mu \mathrm{L}$ of $2 \mathrm{M} \mathrm{H}_{2} \mathrm{SO}_{4}$ and the absorbance at 450nm was measured using an ELISA plate reader. The relative binding activities were presented as the values of O.D. 450. To assess the blockade of spike protein binding to ACE2 by soluble ACE2 and anti-S1 neutralizing antibodies, $400 \mathrm{ng} / \mathrm{mL}$ of S1-Fc protein was 
preincubated with $2 \mu \mathrm{g} / \mathrm{mL}$ of ACE2 or $1 \mu \mathrm{g} / \mathrm{mL}$ of anti-S1 antibodies at room temperature for 20 minutes before incubation with plate-bound ACE2.

\section{Endotoxin Removal}

Endotoxin removal was perform using $0.25 \mathrm{~mL}$ Pierce high-capacity endotoxin removal spin columns (Catalog\# 88273, Thermo Fisher) following the manufacturer's instructions. Briefly, endotoxin removal resin was regenerated by incubation with $0.2 \mathrm{~N} \mathrm{NaOH}$ in 95\% ethanol at room temperature for 2 hours, followed by washes with $2 \mathrm{M} \mathrm{NaCl}$, endotoxin-free ultrapure water and endotoxin-free PBS. The regenerated resin was then incubated with $\mathrm{S} 1-\mathrm{Fc}$ spike protein reagents and streptavidin at $4{ }^{\circ} \mathrm{C}$ overnight. The protein samples were recovered by centrifugation at $500 \times \mathrm{g}$ for 1 minute.

\section{LAL endotoxin measurement}

The levels of endotoxin in spike protein reagents and streptavidin treated with or without high capacity endotoxin removal spin columns were measured using the Pierce ${ }^{\mathrm{TM}}$ LAL Chromogenic Endotoxin Quantitation Kit (Catalog\# 88282, Thermo Fisher) following the manufacturer's instruction. Briefly, $50 \mu \mathrm{L}$ of diluted protein sample and LPS standards were added to each well of a 96-well plate. The plate was warmed to $37^{\circ} \mathrm{C}$ in a water bath. $50 \mu \mathrm{L}$ of limulus amebocyte lysate was added to each well and incubated for 10 minutes following briefly mixing. Then, $100 \mu \mathrm{L}$ of chromogenic substrate solution (prewarmed to $37^{\circ} \mathrm{C}$ ) was added to each well. $100 \mu \mathrm{L}$ of $25 \%$ acetic acid was added to wells to stop the reaction following 6-minute substrate development. The absorbance at $405 \mathrm{~nm}$ was measured using an ELISA plate reader. The concentrations of endotoxin were calculated based on the standard curve created using the absorbance values of the standards.

\section{Statistical analyses}

All statistical analyses were conducted using Excel software and performed using the two-tailed Student's ttest. The significance threshold was set at $p<0.05$.

Author contributions: W.O. and D.F. conceived and designed the study. W.O., T.X., H.F., C.G., T.S. and K.Y. performed the experiments. W.O., T.X., and D.F. analyzed the data. W.O. and D.F. prepared the manuscript. D.F., K.C. and T.J. provided experimental advice. D.F. supervised the study.

Funding: This work was supported by FDA internal funding, including a Medical Countermeasures Initiative grant from the FDA Office of the Chief Scientist.

Acknowledgements: We thank Drs. Xianghong Jing, Brian Roelofs, and Ying-Xin Fan for thoughtful review of the manuscript.

Conflict of interest: The authors declare that they have no conflicts of interest with the contents of this article.

Disclaimer: This manuscript reflects the views of the authors and should not be construed to represent FDA's views or policies. 


\section{REFERENCES}

1. $\quad$ https://www.worldometers.info/coronavirus/\#countries.

2. Zhou, P., Yang, X. L., Wang, X. G., Hu, B., Zhang, L., Zhang, W., Si, H. R., Zhu, Y., Li, B., Huang, C. L., Chen, H. D., Chen, J., Luo, Y., Guo, H., Jiang, R. D., Liu, M. Q., Chen, Y., Shen, X. R., Wang, X., Zheng, X. S., Zhao, K., Chen, Q. J., Deng, F., Liu, L. L., Yan, B., Zhan, F. X., Wang, Y. Y., Xiao, G. F., and Shi, Z. L. (2020) A pneumonia outbreak associated with a new coronavirus of probable bat origin. Nature 579, 270-273

3. Fouchier, R. A., Kuiken, T., Schutten, M., van Amerongen, G., van Doornum, G. J., van den Hoogen, B. G., Peiris, M., Lim, W., Stohr, K., and Osterhaus, A. D. (2003) Aetiology: Koch's postulates fulfilled for SARS virus. Nature 423, 240

4. Kuiken, T., Fouchier, R. A., Schutten, M., Rimmelzwaan, G. F., van Amerongen, G., van Riel, D., Laman, J. D., de Jong, T., van Doornum, G., Lim, W., Ling, A. E., Chan, P. K., Tam, J. S., Zambon, M. C., Gopal, R., Drosten, C., van der Werf, S., Escriou, N., Manuguerra, J. C., Stohr, K., Peiris, J. S., and Osterhaus, A. D. (2003) Newly discovered coronavirus as the primary cause of severe acute respiratory syndrome. Lancet 362, 263-270

5. Ksiazek, T. G., Erdman, D., Goldsmith, C. S., Zaki, S. R., Peret, T., Emery, S., Tong, S., Urbani, C., Comer, J. A., Lim, W., Rollin, P. E., Dowell, S. F., Ling, A. E., Humphrey, C. D., Shieh, W. J., Guarner, J., Paddock, C. D., Rota, P., Fields, B., DeRisi, J., Yang, J. Y., Cox, N., Hughes, J. M., LeDuc, J. W., Bellini, W. J., Anderson, L. J., and Group, S. W. (2003) A novel coronavirus associated with severe acute respiratory syndrome. N Engl J Med 348, 1953-1966

6. Kuba, K., Imai, Y., Rao, S., Gao, H., Guo, F., Guan, B., Huan, Y., Yang, P., Zhang, Y., Deng, W., Bao, L., Zhang, B., Liu, G., Wang, Z., Chappell, M., Liu, Y., Zheng, D., Leibbrandt, A., Wada, T., Slutsky, A. S., Liu, D., Qin, C., Jiang, C., and Penninger, J. M. (2005) A crucial role of angiotensin converting enzyme 2 (ACE2) in SARS coronavirus-induced lung injury. Nat Med 11, 875-879

7. Lan, J., Ge, J., Yu, J., Shan, S., Zhou, H., Fan, S., Zhang, Q., Shi, X., Wang, Q., Zhang, L., and Wang, X. (2020) Structure of the SARS-CoV-2 spike receptor-binding domain bound to the ACE2 receptor. Nature 581, 215-220

8. Papageorgiou, A. C., and Mohsin, I. (2020) The SARS-CoV-2 Spike Glycoprotein as a Drug and Vaccine Target: Structural Insights into Its Complexes with ACE2 and Antibodies. Cells 9

9. $\quad$ Shang, J., Ye, G., Shi, K., Wan, Y., Luo, C., Aihara, H., Geng, Q., Auerbach, A., and Li, F. (2020) Structural basis of receptor recognition by SARS-CoV-2. Nature 581, 221-224

10. Shang, J., Wan, Y., Luo, C., Ye, G., Geng, Q., Auerbach, A., and Li, F. (2020) Cell entry mechanisms of SARS-CoV-2. Proc Natl Acad Sci U S A 117, 11727-11734

11. Xia, S., Lan, Q., Su, S., Wang, X., Xu, W., Liu, Z., Zhu, Y., Wang, Q., Lu, L., and Jiang, S. (2020) The role of furin cleavage site in SARS-CoV-2 spike protein-mediated membrane fusion in the presence or absence of trypsin. Signal Transduct Target Ther 5, 92

12. Rehwinkel, J., and Gack, M. U. (2020) RIG-I-like receptors: their regulation and roles in RNA sensing. Nat Rev Immunol 20, 537-551

13. Saito, T., and Gale, M., Jr. (2008) Differential recognition of double-stranded RNA by RIG-I-like receptors in antiviral immunity. $J$ Exp Med 205, 1523-1527

14. Diebold, S. S., Kaisho, T., Hemmi, H., Akira, S., and Reis e Sousa, C. (2004) Innate antiviral responses by means of TLR7-mediated recognition of single-stranded RNA. Science 303, 1529-1531

15. Alexopoulou, L., Holt, A. C., Medzhitov, R., and Flavell, R. A. (2001) Recognition of doublestranded RNA and activation of NF-kappaB by Toll-like receptor 3. Nature 413, 732-738

16. Chow, K. T., Gale, M., Jr., and Loo, Y. M. (2018) RIG-I and Other RNA Sensors in Antiviral Immunity. Annu Rev Immunol 36, 667-694 
17. Lei, X., Dong, X., Ma, R., Wang, W., Xiao, X., Tian, Z., Wang, C., Wang, Y., Li, L., Ren, L., Guo, F., Zhao, Z., Zhou, Z., Xiang, Z., and Wang, J. (2020) Activation and evasion of type I interferon responses by SARS-CoV-2. Nat Commun 11, 3810

18. Bhaskar, S., Sinha, A., Banach, M., Mittoo, S., Weissert, R., Kass, J. S., Rajagopal, S., Pai, A. R., and Kutty, S. (2020) Cytokine Storm in COVID-19-Immunopathological Mechanisms, Clinical Considerations, and Therapeutic Approaches: The REPROGRAM Consortium Position Paper. Front Immunol 11, 1648

19. Kindler, E., Thiel, V., and Weber, F. (2016) Interaction of SARS and MERS Coronaviruses with the Antiviral Interferon Response. Adv Virus Res 96, 219-243

20. Hadjadj, J., Yatim, N., Barnabei, L., Corneau, A., Boussier, J., Smith, N., Pere, H., Charbit, B., Bondet, V., Chenevier-Gobeaux, C., Breillat, P., Carlier, N., Gauzit, R., Morbieu, C., Pene, F., Marin, N., Roche, N., Szwebel, T. A., Merkling, S. H., Treluyer, J. M., Veyer, D., Mouthon, L., Blanc, C., Tharaux, P. L., Rozenberg, F., Fischer, A., Duffy, D., Rieux-Laucat, F., Kerneis, S., and Terrier, B. (2020) Impaired type I interferon activity and inflammatory responses in severe COVID-19 patients. Science 369, 718-724

21. Wang, N., Zhan, Y., Zhu, L., Hou, Z., Liu, F., Song, P., Qiu, F., Wang, X., Zou, X., Wan, D., Qian, X., Wang, S., Guo, Y., Yu, H., Cui, M., Tong, G., Xu, Y., Zheng, Z., Lu, Y., and Hong, P. (2020) Retrospective Multicenter Cohort Study Shows Early Interferon Therapy Is Associated with Favorable Clinical Responses in COVID-19 Patients. Cell Host Microbe

22. Lee, J. S., and Shin, E. C. (2020) The type I interferon response in COVID-19: implications for treatment. Nat Rev Immunol

23. Thoms, M., Buschauer, R., Ameismeier, M., Koepke, L., Denk, T., Hirschenberger, M., Kratzat, H., Hayn, M., Mackens-Kiani, T., Cheng, J., Straub, J. H., Sturzel, C. M., Frohlich, T., Berninghausen, O., Becker, T., Kirchhoff, F., Sparrer, K. M. J., and Beckmann, R. (2020) Structural basis for translational shutdown and immune evasion by the Nsp1 protein of SARS-CoV-2. Science

24. Channappanavar, R., Fehr, A. R., Vijay, R., Mack, M., Zhao, J., Meyerholz, D. K., and Perlman, S. (2016) Dysregulated Type I Interferon and Inflammatory Monocyte-Macrophage Responses Cause Lethal Pneumonia in SARS-CoV-Infected Mice. Cell Host Microbe 19, 181-193

25. Giamarellos-Bourboulis, E. J., Netea, M. G., Rovina, N., Akinosoglou, K., Antoniadou, A., Antonakos, N., Damoraki, G., Gkavogianni, T., Adami, M. E., Katsaounou, P., Ntaganou, M., Kyriakopoulou, M., Dimopoulos, G., Koutsodimitropoulos, I., Velissaris, D., Koufargyris, P., Karageorgos, A., Katrini, K., Lekakis, V., Lupse, M., Kotsaki, A., Renieris, G., Theodoulou, D., Panou, V., Koukaki, E., Koulouris, N., Gogos, C., and Koutsoukou, A. (2020) Complex Immune Dysregulation in COVID-19 Patients with Severe Respiratory Failure. Cell Host Microbe 27, 9921000 e1003

26. Mathew, D., Giles, J. R., Baxter, A. E., Oldridge, D. A., Greenplate, A. R., Wu, J. E., Alanio, C., Kuri-Cervantes, L., Pampena, M. B., D'Andrea, K., Manne, S., Chen, Z., Huang, Y. J., Reilly, J. P., Weisman, A. R., Ittner, C. A. G., Kuthuru, O., Dougherty, J., Nzingha, K., Han, N., Kim, J., Pattekar, A., Goodwin, E. C., Anderson, E. M., Weirick, M. E., Gouma, S., Arevalo, C. P., Bolton, M. J., Chen, F., Lacey, S. F., Ramage, H., Cherry, S., Hensley, S. E., Apostolidis, S. A., Huang, A. C., Vella, L. A., Unit, U. P. C. P., Betts, M. R., Meyer, N. J., and Wherry, E. J. (2020) Deep immune profiling of COVID-19 patients reveals distinct immunotypes with therapeutic implications. Science

27. Blanco-Melo, D., Nilsson-Payant, B. E., Liu, W. C., Uhl, S., Hoagland, D., Moller, R., Jordan, T. X., Oishi, K., Panis, M., Sachs, D., Wang, T. T., Schwartz, R. E., Lim, J. K., Albrecht, R. A., and tenOever, B. R. (2020) Imbalanced Host Response to SARS-CoV-2 Drives Development of COVID19. Cell 181, 1036-1045 e1039

28. Vabret, N., Britton, G. J., Gruber, C., Hegde, S., Kim, J., Kuksin, M., Levantovsky, R., Malle, L., Moreira, A., Park, M. D., Pia, L., Risson, E., Saffern, M., Salome, B., Esai Selvan, M., Spindler, M. 
P., Tan, J., van der Heide, V., Gregory, J. K., Alexandropoulos, K., Bhardwaj, N., Brown, B. D., Greenbaum, B., Gumus, Z. H., Homann, D., Horowitz, A., Kamphorst, A. O., Curotto de Lafaille, M. A., Mehandru, S., Merad, M., Samstein, R. M., and Sinai Immunology Review, P. (2020) Immunology of COVID-19: Current State of the Science. Immunity 52, 910-941

29. Lucas, C., Wong, P., Klein, J., Castro, T. B. R., Silva, J., Sundaram, M., Ellingson, M. K., Mao, T., Oh, J. E., Israelow, B., Takahashi, T., Tokuyama, M., Lu, P., Venkataraman, A., Park, A., Mohanty, S., Wang, H., Wyllie, A. L., Vogels, C. B. F., Earnest, R., Lapidus, S., Ott, I. M., Moore, A. J., Muenker, M. C., Fournier, J. B., Campbell, M., Odio, C. D., Casanovas-Massana, A., Yale, I. T., Herbst, R., Shaw, A. C., Medzhitov, R., Schulz, W. L., Grubaugh, N. D., Dela Cruz, C., Farhadian, S., Ko, A. I., Omer, S. B., and Iwasaki, A. (2020) Longitudinal analyses reveal immunological misfiring in severe COVID-19. Nature 584, 463-469

30. Zhang, J. Y., Wang, X. M., Xing, X., Xu, Z., Zhang, C., Song, J. W., Fan, X., Xia, P., Fu, J. L., Wang, S. Y., Xu, R. N., Dai, X. P., Shi, L., Huang, L., Jiang, T. J., Shi, M., Zhang, Y., Zumla, A., Maeurer, M., Bai, F., and Wang, F. S. (2020) Single-cell landscape of immunological responses in patients with COVID-19. Nat Immunol 21, 1107-1118

31. Cao, X. (2020) COVID-19: immunopathology and its implications for therapy. Nat Rev Immunol 20 , 269-270

32. Tay, M. Z., Poh, C. M., Renia, L., MacAry, P. A., and Ng, L. F. P. (2020) The trinity of COVID-19: immunity, inflammation and intervention. Nat Rev Immunol 20, 363-374

33. Cevik, M., Tate, M., Lloyd, O., Maraolo, A. E., Schafers, J., and Ho, A. (2021) SARS-CoV-2, SARS-CoV, and MERS-CoV viral load dynamics, duration of viral shedding, and infectiousness: a systematic review and meta-analysis. Lancet Microbe 2, e13-e22

34. Wang, W., Ye, L., Ye, L., Li, B., Gao, B., Zeng, Y., Kong, L., Fang, X., Zheng, H., Wu, Z., and She, Y. (2007) Up-regulation of IL-6 and TNF-alpha induced by SARS-coronavirus spike protein in murine macrophages via NF-kappaB pathway. Virus Res 128, 1-8

35. Ramakrishnan, S., Nicolau, D. V., Jr., Langford, B., Mahdi, M., Jeffers, H., Mwasuku, C., Krassowska, K., Fox, R., Binnian, I., Glover, V., Bright, S., Butler, C., Cane, J. L., Halner, A., Matthews, P. C., Donnelly, L. E., Simpson, J. L., Baker, J. R., Fadai, N. T., Peterson, S., Bengtsson, T., Barnes, P. J., Russell, R. E. K., and Bafadhel, M. (2021) Inhaled budesonide in the treatment of early COVID-19 (STOIC): a phase 2, open-label, randomised controlled trial. Lancet Respir Med

36. Hsu, A. C., Wang, G.Q., Reid, A.T., Veerati, P.C., Pathinayake, P.S., Daly, K., Mayall, J.R., Hansbro, P.M., Horvat, J.C., Wang, F. and Wark, P.A. (2020) SARS-CoV-2 Spike protein promotes hyperinflammatory response that can be ameliorated by Spike-antagonistic peptide and FDA-approved ER stress and MAP kinase inhibitors in vitro. bioRxiv, doi: 10.1101/2020.1109.1130.317818

37. Crabtree, G. R., and Olson, E. N. (2002) NFAT signaling: choreographing the social lives of cells. Cell 109 Suppl, S67-79

38. Park, Y. J., Yoo, S. A., Kim, M., and Kim, W. U. (2020) The Role of Calcium-Calcineurin-NFAT Signaling Pathway in Health and Autoimmune Diseases. Front Immunol 11, 195

39. Petruk, G., Puthia, M., Petrlova, J., Samsudin, F., Stromdahl, A. C., Cerps, S., Uller, L., Kjellstrom, S., Bond, P. J., and Schmidtchen, A. A. (2021) SARS-CoV-2 spike protein binds to bacterial lipopolysaccharide and boosts proinflammatory activity. J Mol Cell Biol 12, 916-932

40. Jansky, L., Reymanova, P., and Kopecky, J. (2003) Dynamics of cytokine production in human peripheral blood mononuclear cells stimulated by LPS or infected by Borrelia. Physiol Res 52, 593598

41. Byambasuren, O., Cardona, M., Bell, K., Clark, J., McLaws, M. and Glasziou, P. (2020) Estimating the extent of asymptomatic COVID-19 and its potential for community transmission: systematic review and meta-analysis. JAMMI 5, 223-234 
42. Wiersinga, W. J., Rhodes, A., Cheng, A. C., Peacock, S. J., and Prescott, H. C. (2020) Pathophysiology, Transmission, Diagnosis, and Treatment of Coronavirus Disease 2019 (COVID-19): A Review. JAMA 324, 782-793

43. Shoji, T., Yoshida, S., Mitsunari, M., Miyake, N., Tsukihara, S., Iwabe, T., Harada, T., and Terakawa, N. (2007) Involvement of p38 MAP kinase in lipopolysaccharide-induced production of pro- and anti-inflammatory cytokines and prostaglandin E(2) in human choriodecidua. $J$ Reprod Immunol 75, $82-90$

44. Shirato, K., and Kizaki, T. (2021) SARS-CoV-2 spike protein S1 subunit induces pro-inflammatory responses via toll-like receptor 4 signaling in murine and human macrophages. Heliyon 7, e06187

45. Ma, A., Zhang, L., Ye, X., Chen, J., Yu, J., Zhuang, L., Weng, C., Petersen, F., Wang, Z., and Yu, X. (2021) High Levels of Circulating IL-8 and Soluble IL-2R Are Associated With Prolonged Illness in Patients With Severe COVID-19. Front Immunol 12, 626235

46. Sanda, M., Morrison, L., and Goldman, R. (2020) N and O glycosylation of the SARS-CoV-2 spike protein. bioRxiv, doi: 10.1101/2020.1107.1105.187344

47. Gao, C., Zeng, J., Jia, N., Stavenhagen, K., Matsumoto, Y., Zhang, H., Li, J., Hume, A. J., Muhlberger, E., van Die, I., Kwan, J., Tantisira, K., Emili, A., and Cummings, R. D. (2020) SARSCoV-2 Spike Protein Interacts with Multiple Innate Immune Receptors. bioRxiv, doi: 10.1101/2020.1107.1129.22746

48. Kruglikov, I. L., Shah, M., and Scherer, P. E. (2020) Obesity and diabetes as comorbidities for COVID-19: Underlying mechanisms and the role of viral-bacterial interactions. Elife 9 


\section{Figure Legends}

Fig. 1. Dose-dependent cytokine responses of human PBMC induced by SARS CoV-2 S1-Fc fusion protein. Rested PBMC from two healthy donors (HD1 and HD2) were cultured for 48 hours with 0, 0.4, 1.0 and 2.5 $\mu \mathrm{g} / \mathrm{mL}$ of S1-Fc purchased from Vendor \#1 (lot 24056-2002-2). The levels of IL-1 $\beta$, IL-6, IL-8, IL-10, IL-12 and TNF $\alpha$ in the supernatants of cultured PBMC were assessed using the CBA human inflammatory cytokine kit and flow cytometric analysis. Data shown are representative of the flow cytometric results from two independent experiments with total three healthy donors.

Fig. 2. Cytokine responses in human PBMC induced by various commercial coronavirus spike proteins. (A) Rested PBMC were cultured with or without $2.0 \mu \mathrm{g} / \mathrm{mL}$ of raxibacumab (human anti-anthrax PA IgG used as a negative control), MERS S1-Fc, SARS CoV-1 S1-Fc, SARS CoV-2 S1-Fc from Vendor \#2 (V\#2 S1-Fc) and Vendor \#1 (lot 24529-2003, V\#1 S1-Fc 2003), and RBD-Fc from Vendor \#2 (V\#2 RBD-Fc) and Vendor \#1 (lot 24530-2003, V\#1 RBD-Fc 2003) for 24 hours. (B) Rested PBMC were cultured with or without plate-bound streptavidin (STAV) together with or without S1-biotin and RBD-biotin purchased from Vendor \#2. The levels of IL-6 and TNF $\alpha$ were measured using the CBA human inflammatory cytokine kit and flow cytometric analysis. IL-8 levels were measured using an ELISA kit. The concentrations of the cytokines were calculated based on the standard curves, and the induction of cytokines were presented as stimulation indices. Data shown are statistical results (mean \pm SE) generated from 8 (A) or 3 (B) healthy donors. Statistical analyses were performed by Excel using a two-tailed, Student's T-test. *, **, *** and **** depict $p<0.05,0.01,0.005$ and 0.001 , respectively.

Fig. 3. Inhibition of S1-Fc-induced cytokine responses by budesonide and MAPK inhibitors. Rested PBMC were cultured with or without $2.0 \mu \mathrm{g} / \mathrm{mL}$ of S1-Fc from Vendor \#2 in the presence or absence of budesonide, U0126 (MEK1/2 inhibitor, Erk1/2i), SP600125 (JNK1/2 inhibitor, JNK1/2i) or SB203580 (p38 inhibitor, p38i) for 24 hours. The levels of IL-6, TNF $\alpha$ and IL-8 were measured as described in Figure 2. Data shown are mean $\pm \mathrm{SE}$ of the stimulation indices derived from 8 healthy donors, which were calculated using cytokine concentrations measured by the CBA assay (IL-6 and TNF $\alpha$ ) or the ELISA (IL-8). Statistical analyses were performed using a two-tailed, Student's T-test. * and ** depict $p<0.05$ and 0.01 , respectively.

Fig. 4. SARS CoV-2 spike protein-induced cytokine production is independent of its binding to ACE2. (A) The binding activities of coronaviral spike Fc fusion proteins to ACE2 were measured using an ELISA. The binding activities of 16, 80, 400 and $2000 \mathrm{ng} / \mathrm{mL}$ of the indicated proteins were presented as absorbance at $450 \mathrm{~nm}$ (O.D. 450). (B) Inhibition of S1-Fc binding to ACE2 by soluble ACE2 or a neutralizing anti-S1 antibody. $400 \mathrm{ng} / \mathrm{mL}$ of S1-Fc was preincubated with or without $2 \mu \mathrm{g} / \mathrm{mL}$ of soluble ACE2, $1 \mu \mathrm{g} / \mathrm{mL}$ of neutralizing (nAb) or non-neutralizing (non-nAb) anti-S1 antibody before incubation with plate-bound ACE2. Statistical analyses were performed using a two-tailed, Student's T-test. *** depicts $p<0.001$. (C) Rested PBMC were cultured with or without $2.0 \mu \mathrm{g} / \mathrm{mL}$ of S1-Fc in the presence or absence of $5 \mu \mathrm{g} / \mathrm{mL}$ of soluble ACE2, $2 \mu \mathrm{g} / \mathrm{mL}$ of nAb or non-Ab for 24 hours. The levels of IL-6, IL-8 and TNF $\alpha$ in the supernatants of cultured PBMC were assessed using the CBA human inflammatory cytokine kit and flow cytometric analysis.

Fig. 5. LPS co-purifying with spike protein reagents induces proinflammatory cytokine production. (A) MERS S1-Fc, SARS CoV-1 S1-Fc, S1-Fc from Vendor \#2 (V\#2 S1-Fc), S1-Fc from Vendor \#1 (lot 240562002-2 (V\#1 S1-Fc 2002) and lot 24529-2003 (V\#1 S1-Fc 2003)), RBD-Fc from Vendor \#2 (V\#2 RBD-Fc) and RBD-Fc from Vendor \#1 (lot 25130-2004, V\#1 RBD-Fc 2004), and (B) V\#2 S1-Fc, V\#1 S1-Fc 2002 and streptavidin (STAV) before and after treatment of endotoxin removal were assessed for the levels of endotoxin using the LAL Chromogenic Endotoxin Quantitation Kit. The concentrations of endotoxin are presented as EU/mg protein. Data shown are mean $\pm \mathrm{SE}$ of the results from three independent experiments. 
(C) Time course of S1-Fc-induced cytokine responses. Rested PBMC were cultured with or without 2.0 $\mu \mathrm{g} / \mathrm{mL}$ of S1-Fc (V\#2 S1-Fc and V\#1 S1-Fc 2002) for 1, 3, 6 or 24 hours. The levels of IL-6, IL-8 and TNF $\alpha$ in the supernatants of cultured PBMC were assessed using the CBA human inflammatory cytokine kit and flow cytometric analysis. (D, E) Blockade of S1-Fc-induced cytokine response by an LPS inhibitor, polymyxin B. Rested PBMC were cultured with or without $2.0 \mu \mathrm{g} / \mathrm{mL}$ of S1-Fc (V\#2 S1-Fc) in the presence or absence of polymyxin B for 3 hours. The levels of IL-6, IL-8 and TNF $\alpha$ in the supernatants of cultured PBMC were measured using the CBA human inflammatory cytokine kit and flow cytometric analysis. Data shown in (D) are a representative of the flow cytometric results from three healthy donors and data shown in (E) are mean \pm SE of the stimulation index derived from three healthy donors, which is calculated using mean fluorescent intensities (MFI) of the cytokines and the formula: cytokine MFI of treated PBMC/cytokine MFI of untreated PBMC. Statistical analyses were performed using a two-tailed, Student's T-test. * and ** depict $p<0.05$ and 0.01 , respectively.

Fig. 6. Spike protein captures endotoxin to induce cytokine expression. Rested PBMC were cultured for 3 hours in wells, which were coated with or without $100 \mu \mathrm{L}$ of streptavidin (STAV, $2.0 \mu \mathrm{g} / \mathrm{mL}$ ) and S1-biotion from Vendor \#1 together with $0.15,0.3$ or 0.6 EU/mL LPS. The levels of IL-6, IL-8 and TNF $\alpha$ in the supernatants of cultured PBMC were measured using the CBA human inflammatory cytokine kit and flow cytometric analysis. The concentrations of IL-8 in the supernatants were also measured using an ELISA kit. Data shown in (A) are a representative of the flow cytometric results from four healthy donors, and data shown in (B) are mean \pm SE of the stimulation indices derived from four healthy donors, which were calculated using cytokine concentrations measured by the CBA assay (IL-6 and TNF $\alpha$ ) or the ELISA (IL-8). Statistical analyses were performed using two-tailed, Student's T-test. * and ** depict $p<0.05$ and 0.01 , respectively. 
bioRxiv preprint doi: https://doi.org/10.1101/2021.05.26.445843; this version posted May 26, 2021. The copyright holder for this preprint (which

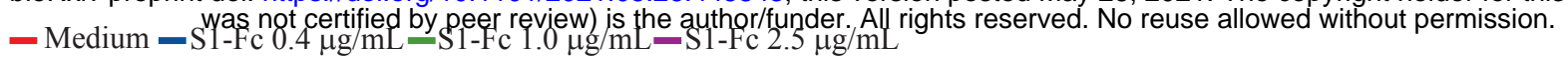

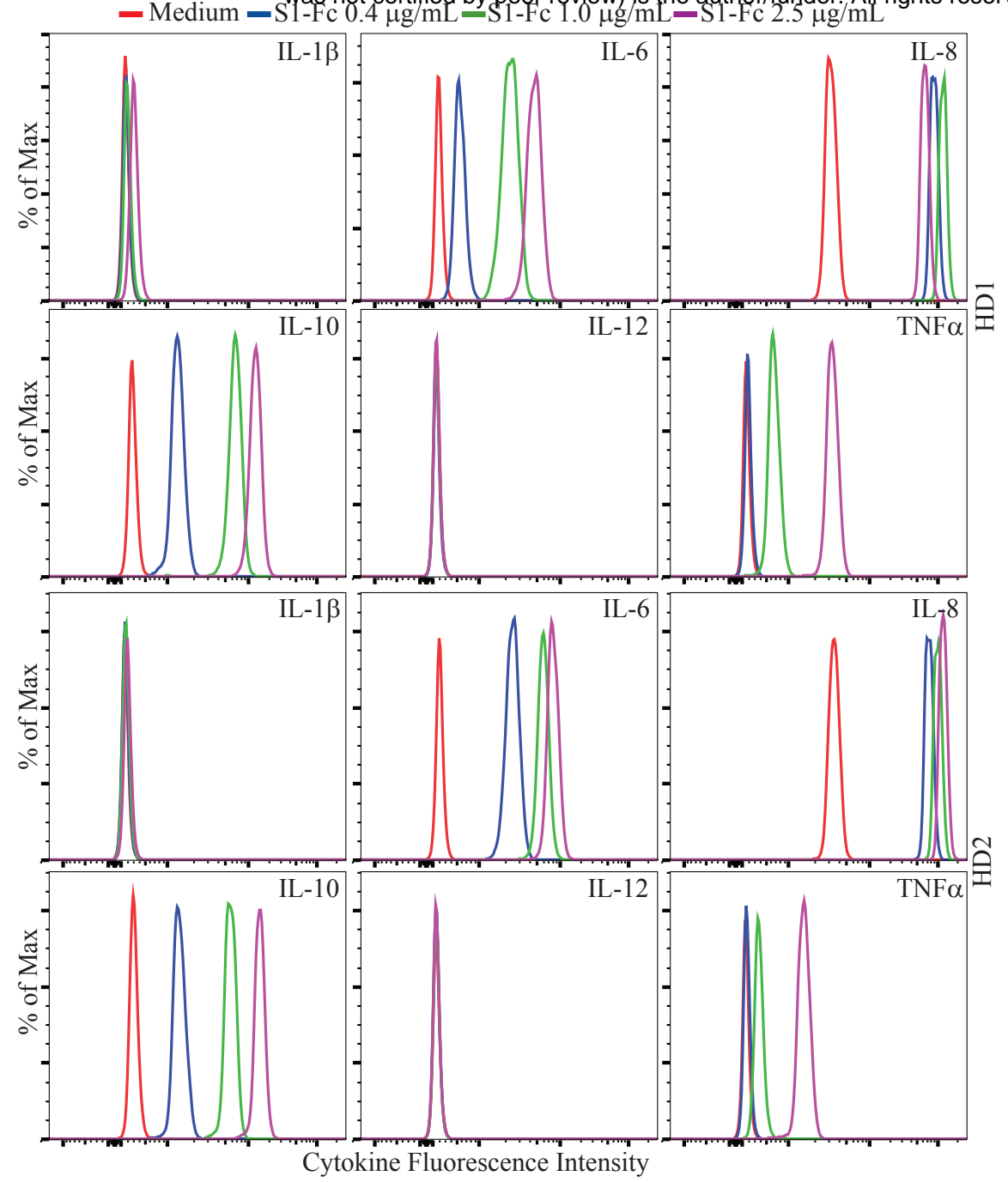

Figure 1 
bioRxiv preprint doi: https://doi.org/10.1101/2021.05.26.445843; this version posted May 26, 2021. The copyright holder for this preprint (which

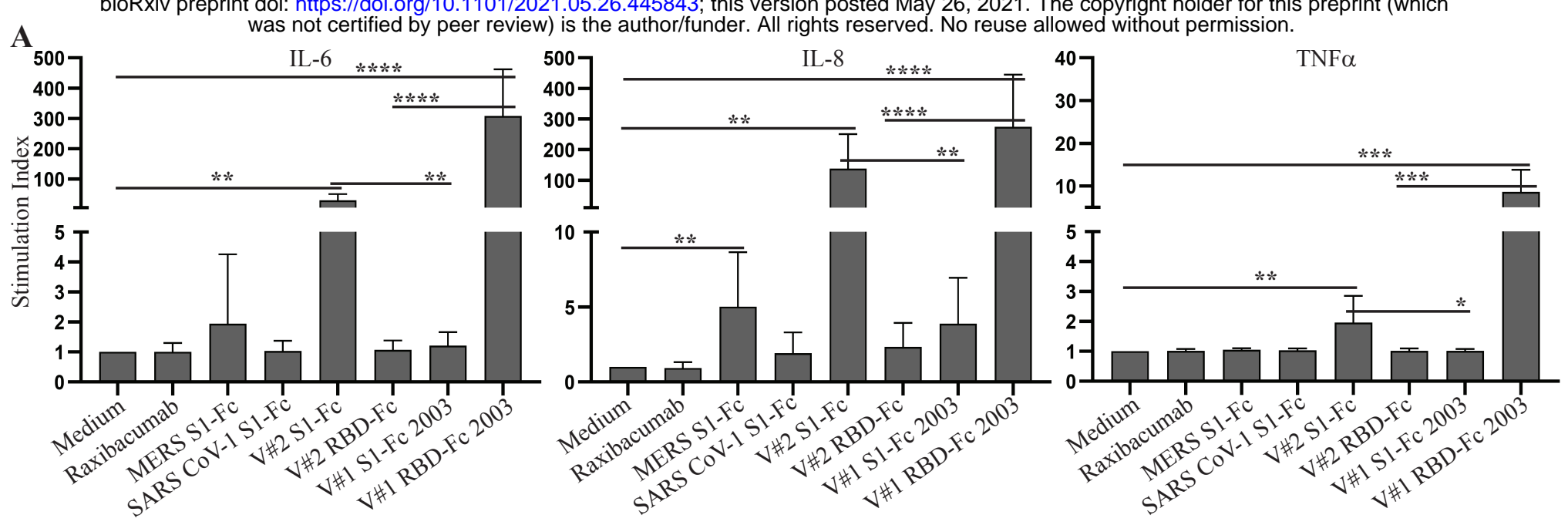

B
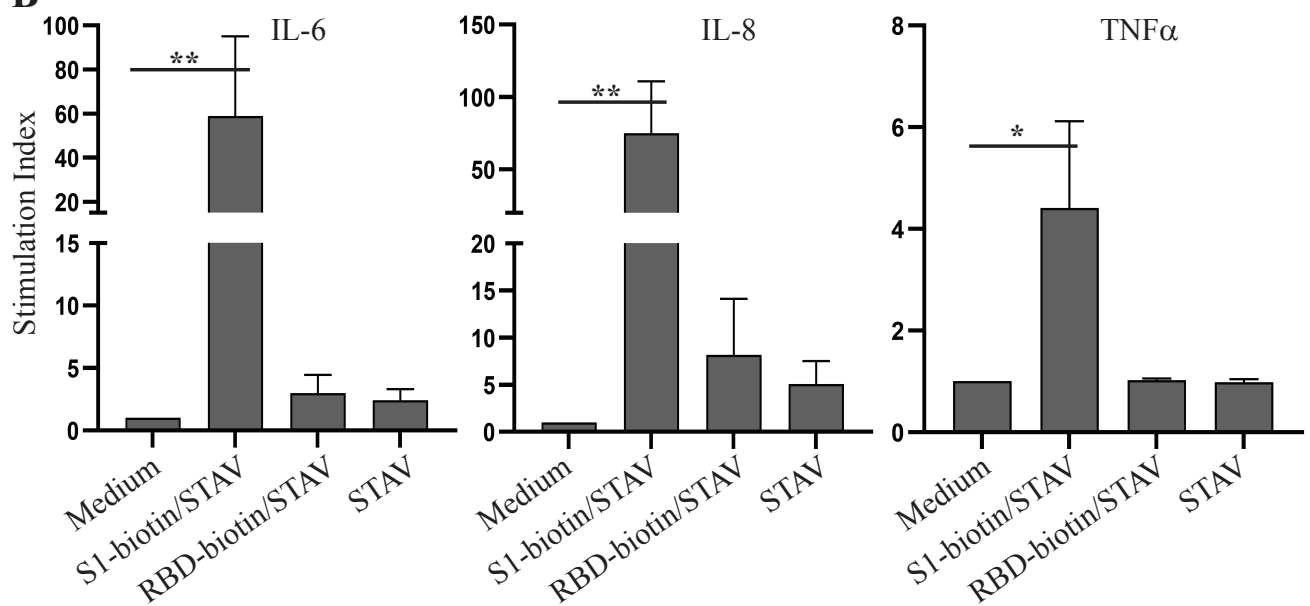

Figure 2 
bioRxiv preprint doi: https://doi.org/10.1101/2021.05.26.445843; this version posted May 26, 2021. The copyright holder for this preprint (which was not certified by peer review) is the author/funder. All rights reserved. No reuse allowed without permission.
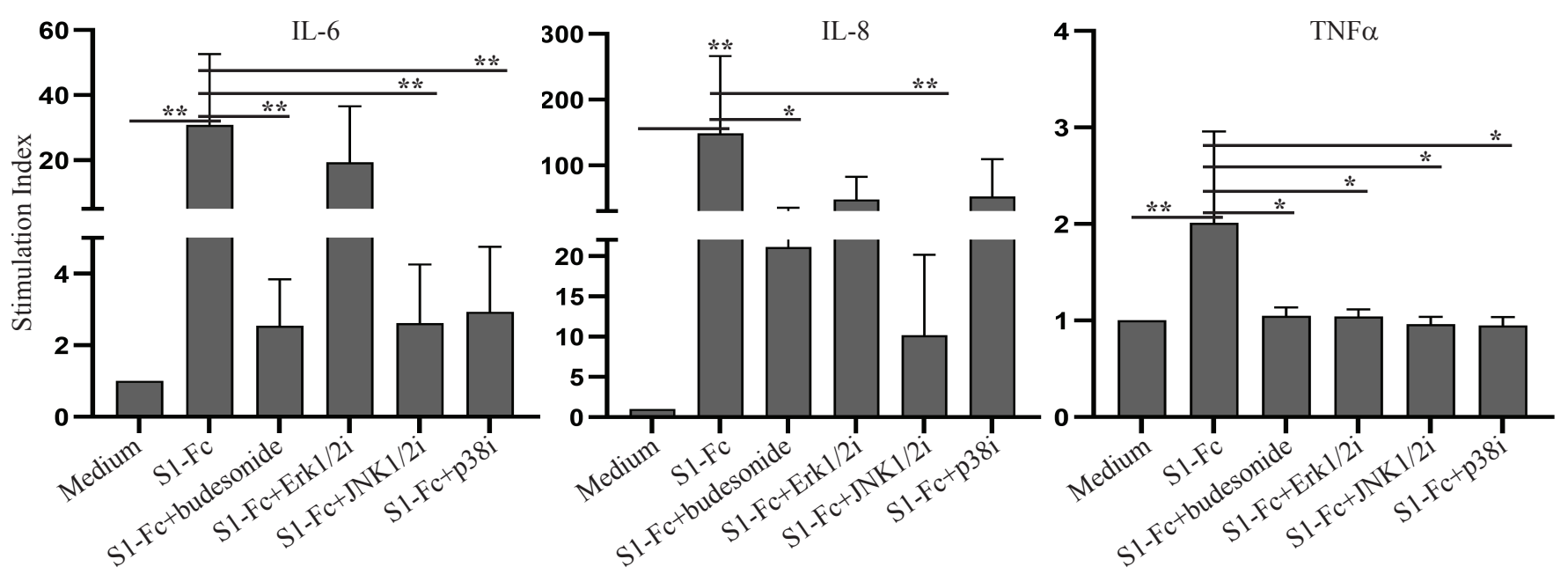

Figure 3 
bioRxiv preprint doi: https://doi.org/10.1101/2021.05.26.445843; this version posted May 26, 2021. The copyright holder for this preprint (which

A was not certified by peer review) is the author/funder. All rights reserved. No reuse allowed without permission.

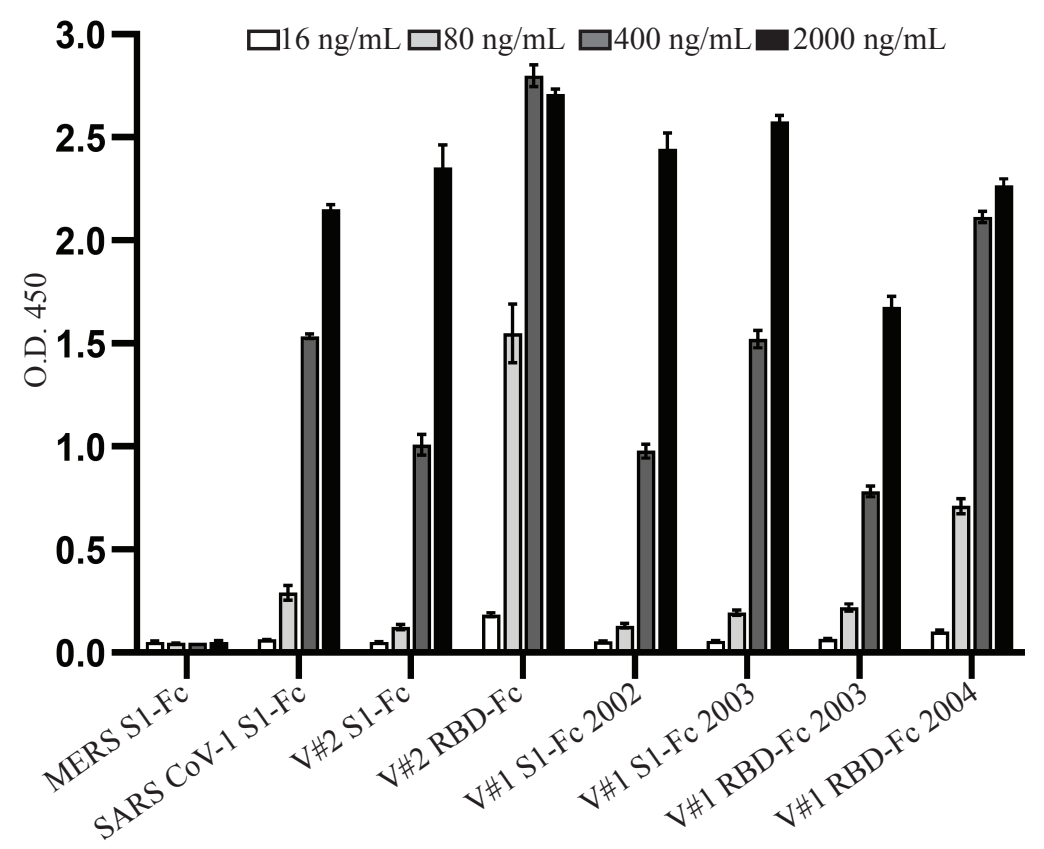

$\mathbf{B}$
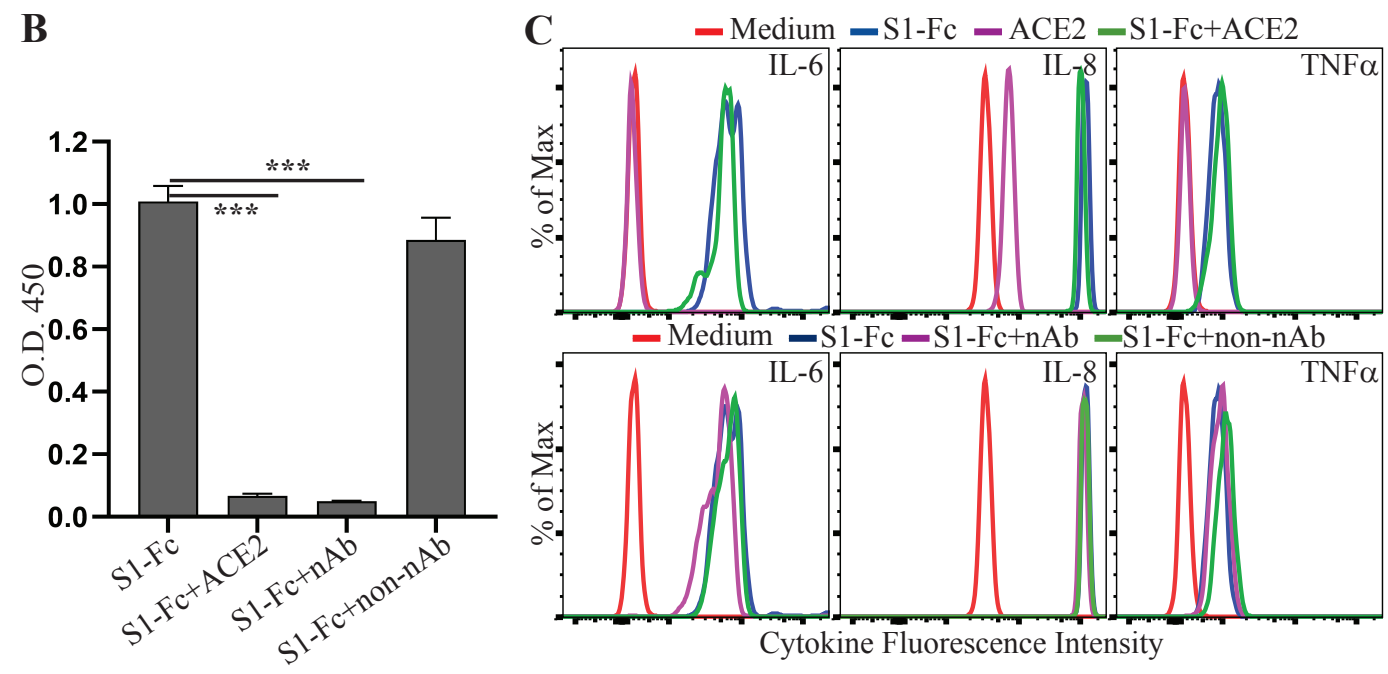

Figure 4 
bioRxiv preprint doi: https://doi.org/10.1101/2021.05.26.445843; this version posted May 26, 2021. The copyright holder for this preprint (which
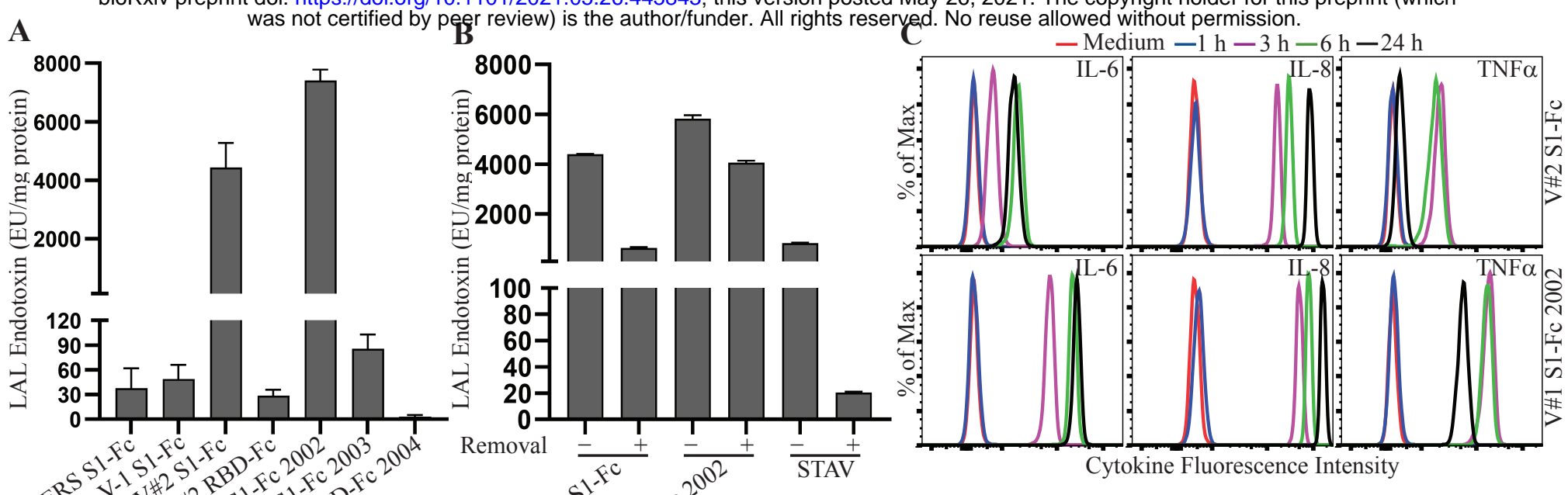

D

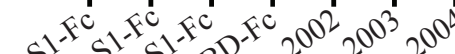
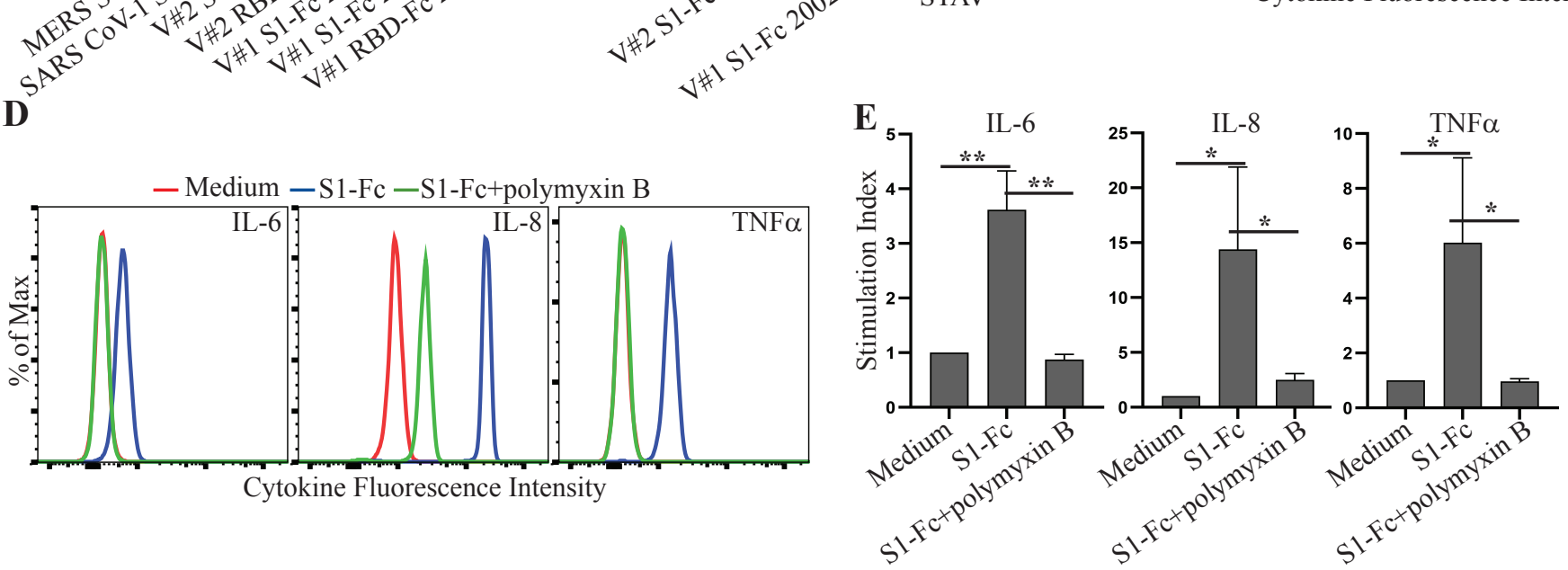

Figure 5 
bioRxiv preprint doi: https://doi.org/10.1101/2021.05.26.445843; this version posted May 26, 2021. The copyright holder for this preprint (which

A was not certified by peer review) is the author/funder. All rights reserved. No reuse allowed without permission.
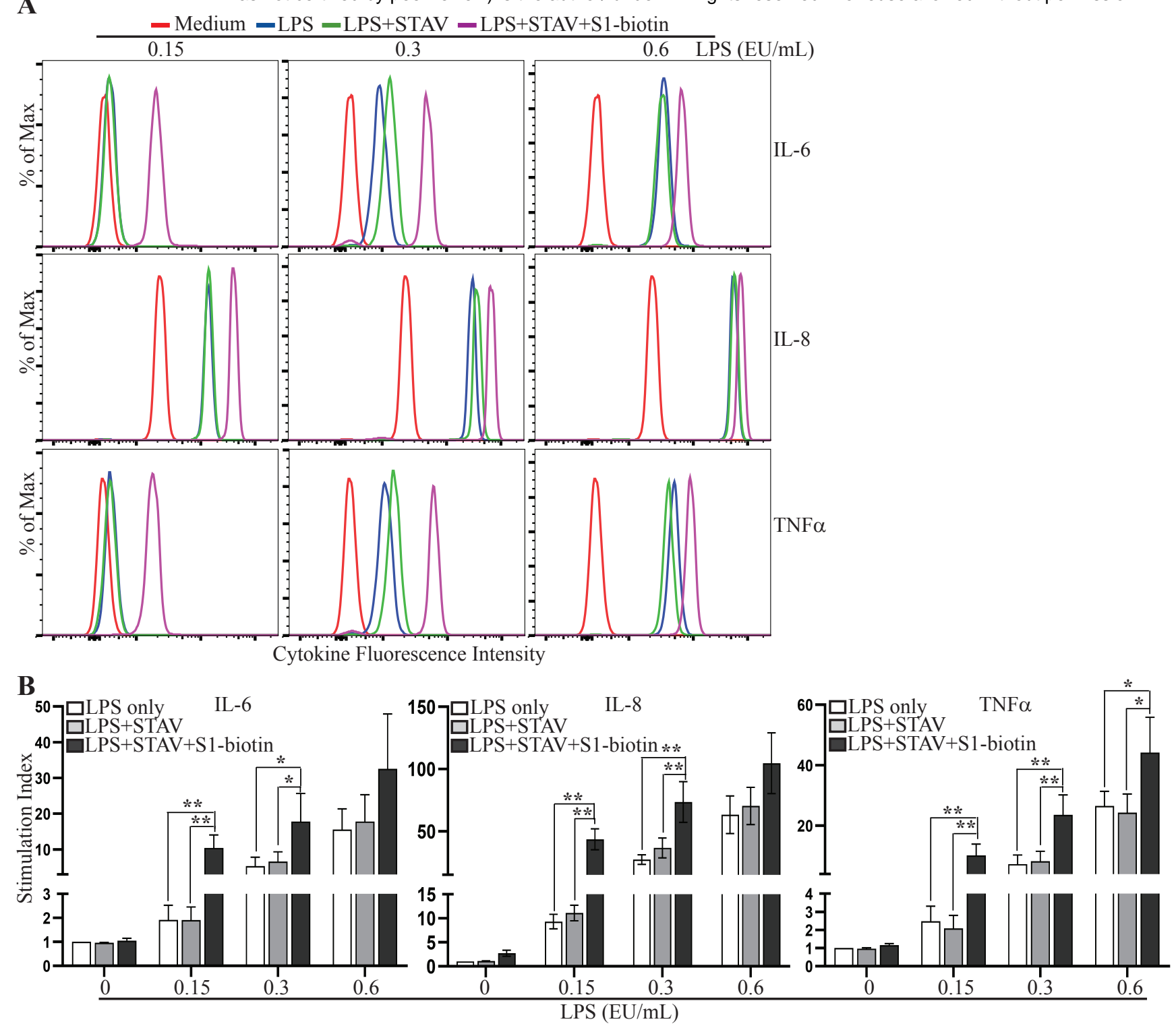

Figure 6 